\title{
Legal Historical Researcb in Belgium (2018)
}

Keywords: conference, publication, legal history, Belgium, doctoral defences

Słowa kluczowe: konferencja, publikacja, historia prawa, Belgia, obrony doktoratów

\section{Introduction}

It has become a good tradition in this review to present the most important events and accomplishments in Belgian legal historical research during the past year. This contribution deals with conferences, publications, and Ph.D. defences, which have taken place in Belgium in the year 2018. Three preliminary remarks are necessary. First, this contribution does not aim to be an exhaustive overview of all publications. Secondly, given the international nature of current academic research, it is almost impossible to separate Belgian legal historical work from events in European legal history and even beyond. Therefore, the focus will be only on the conferences that have taken place in Belgium, and on books that were (co-)authored or (co-)edited by legal historians active at Belgian universities. Thirdly, although I tried to take into account the French speaking universities of Belgium as well, I am more familiar with the Flemish ones.

\section{Conferences}

Several legal historical conferences took place in Belgium in the year 2018.

On 16 February 2018, legal historians gathered in Ghent for a lecture by Prof. Dr. Isabel Graes of the University of Lisbon on the history of the Portuguese justice system in the $19^{\text {th }}$ century, and particularly on the influence of the French liberal model (L'histoire de la justice portugaise au XIXe siècle et l'influence du modèle français). 
A few days later, on 19 February 2018, Prof. Dr. Stephen Neff (University of Edinburgh) gave a lecture at the same university of Ghent on the standard of civilization in international law, where he also referred to the legal historical background. The lecture was followed by a seminar.

On 16 March 2018, a new gathering in Ghent concerned the Norwegian legal system and hosted lectures by two colleagues from the university of Bergen in Norway, namely Prof. Dr. Ragna Aarli and Prof. Dr. Jørn Øyrehagen Sunde. Whereas the former focused on the findings of the commission that was charged with the preparation of the reform of the justice system, the latter offered legal historical reflections. Prof. Sunde's lecture was entitled The Four Daughters of God in Norwegian Law in the High Middle Ages.

On 25 April 2018, Dr. Sebastiaan Vandenbogaerde (UGent) presented his research on the influence of the First World War on Belgian private law at KU Leuven. His lecture was entitled Het Belgische privaatrecht tot een ruïne herleid (1914-1940).

From 24 till 26 May 2018, the University of Saint-Louis (Brussels) organized an international conference on Power, Authority and Normativity in Medieval Culture and War. Papers dealt with how medieval warfare contributed to the formation of balances of power, and how in their turn those power relationships formed and influenced the organization and techniques of warfare.

On 30-31 May 2018, the colleagues from UCLouvain (Louvain-la-Neuve) hosted an international conference on Popular Policing in Europe (18 $8^{\text {th }}-20^{\text {th }}$ Centuries). As of the eighteenth century, the monopoly of violence resided with the nation states. Did those nation states still leave some room for 'popular justice'? Especially in times of political transition, or in failed states, (parts of) the people revolted and organized 'voluntary policing' or vigilantes. The conference focused inter alia on how these groups related to and interacted with the governmental policing system.

From 20 to 22 September 2018, another international conference was held at KU Leuven. That conference concerned legal and institutional translation policies. Translation studies is a rapidly expanding field of research, which interests scholars from a variety of backgrounds, including legal history. This conference focused on both past and present translation policies from four main angles: multilingualism, legal settings, institutional settings and citizenship.

On 18-19 October 2018, the Brussels Free Universities (VUB and ULB) co-organized a conference on German professors in Belgium (Les professeurs allemands en Belgique: Circulation des saviors juridiques et enseignement du droit). Traditionally, the Belgian legal system is said to have been influenced especially by its French counterpart. In the nineteenth century, however, also various German professors, amongst whom for instance the criminal lawyer Jacques-Joseph Haus (1796-1881) and the legal historian Leopold August Warnkönig (1794-1866), had an appointment at Belgian universities. This conference studied the extent to which this German presence also stimulated the circulation of German legal ideas and juridical knowledge.

On 19 October 2018, the KU Leuven organized an emeritus celebration for Prof. Dr. Laurent Waelkens (KU Leuven), who had held the chair of Roman law at KU Leuven as of 2004. In his final lecture, Prof. Waelkens warned against an a-historical reading of Roman law. His lecture was entitled Romanum ius moliti sumus. De mooiste droom van de rechtsfaculteiten ("We have constructed the Roman law ourselves. The most beautiful 
dream of the law faculties"). At this event, a first copy of the festive volume in his honour was offered. That Festschrift was edited by the students of Prof. Waelkens, among whom also the author of this article, together with Prof. Dr. Wim Decock, Dr. Paolo Angelini, and Drs. Matthias Castelein. The book is entitled Ius commune graeco-romanum.

On 18-19 December 2018, Dr. Raphaël Cahen (VUB) organized - together with Prof. Dr. Nicolas Laurent-Bonne of the university of Clermont-Ferrand - a conference on Joseph-Marie Portalis, the son of one of the writers of Napoléon's Civil Code, but also a diplomat, minister and academic. The conference studied Portalis' activities as a diplomate, his political views, his work as a judge, his religious convictions and the relationship to his father's work.

Finally, on 19 December 2018, the KU Leuven Research Unit of Roman Law and Legal History hosted a guest lecture by Prof. Dr. Wolfgang Ernst (Oxford / Zürich) on Aquilian Liability and the Interruption of the Chain of Causation (D. 9.2.11.3 v. D. 9.2.51). A Digest-Problem and Its History.

\section{Publications}

Belgian legal historians have been very active in 2018 . This contribution will only list books on legal history and will therefore not focus on the many articles that have been written as well. Given the very diverse topics, I have opted to put them in an alphabetical order by author.

Several editors, among whom also Prof. Dr. Dave De ruysscher (VUB / Tilburg University), published a collective volume on the sources of early modern commercial law. The other editors are Prof. Dr. Heikki Pihlajamäki, Prof. Dr. Albrecht Cordes and Prof. Dr. Serge Dauchy. It is entitled Understanding the Sources of Early Modern and Modern Commercial Law: Courts, Statutes, Contracts, and Legal Scholarship (Leyden, Brill).

Prof. Dr. Frederik Dhondt (VUB / UA) wrote a new textbook with an introduction to the history of public law from a comparative perspective. It was published in Brussels by ASP and entitled Gestolde macht: Historische en vergelijkende inleiding tot het publiekrecht.

The author of this chronicle published a short study on the concept of scandalum in medieval canon law among the early commentators of the Decretum Gratiani and the papal decretals until the Liber Extra of 1234. This study is entitled Scandalum in the Early Bolognese Decretistic and in Papal Decretals (ca. 1140-1234) [Spicilegium Sacrum Lovaniense, 55] (Leuven, Peeters).

Prof. Dr. Stephan Dusil (KU Leuven) published his habilitation on the system of medieval juridical knowledge in pre-Gratian collections, in the Decree of Gratian and in the canon law glosses and commentaries between 1000 and 1215 . He illustrates the more general findings on the basis of a study of the evolution of the papal jurisdictional primacy and on celibacy. The book was written in German and entitled Wissensordnungen des Rechts im Wandel. Päpstlicher Jurisdiktionsprimat und Zölibat zwischen 1000 und 1215 (Leuven, University Press). 
Dr. Vincent Genin (KU Leuven / ULiège) studied the works by specialists of international law in nineteenth-century Belgium in his study entitled Le laboratoire belge $d u$ droit international (Brussels, Académie Royale de Belgique). The book explicitly adopts an interdisciplinary approach and takes into account history, law and sociology. The book formulates the hypothesis that the neutral state of Belgium served as laboratory of public international law from 1869 till 1914.

Last year, the same author Dr. Genin also published a longer academic study on international law in Belgium during the Interbellum. In his book, entitled Incarner le droit international. Du mythe juridique au déclassement international de la Belgique (1914-1940) (Bern, Peter Lang), the author studies how Belgian international lawyers coped with the loss of Belgium's neutrality after the First World War.

Prof. Dr. Stanislas Horvat (Royal Military Academy) published the English version of his study on the Belgian courts-martial during the First World War. The book describes and evaluates in detail the application and the procedures of the martial law. It is entitled: Belgian Courts-Martial. Prosecution of Military Law Offences During World War I (Brussels, ASP).

Dr. Stefan Huygebaert, Prof. Dr. Georges Martyn, Dr. Vanessa Paumen, Prof. Dr. Eric Bousmar and Prof. Dr. Xavier Rousseaux commonly edited an interesting volume on the relationship between art and law with contributions by historians, legal historians and art historians. It is entitled The Art of Law: Artistic Representations and Iconography of Law and Justice in Context, from the Middle Ages to the First World War [Ius Gentium, Comparative Perspectives on Law and Justice, 66] (Cham, Springer).

The same Dr. Stefan Huygebaert (UGent) also co-edited a volume on the aesthetical forms of a nation and its constitution. The volume is entitled Sensing the Nation's Law: Historical Inquiries into the Aesthetics of Democratic Legitimacy [Studies in the History of Law and Justice, 13] (Cham, Springer).

Still in 2018, the doctoral dissertation by Dr. Sebastiaan Vandenbogaerde (UGent) was published. In his thesis, the author studies the origins, actors and most important subjects of Belgium's law journals as of the Belgian independence in 1830. The study is entitled Vectoren van het recht. Geschiedenis van de Belgische juridische tijdschriften (Bruges, Die Keure).

Dr. Jan Verstraete published a biography of René Victor (René Victor. 1897-1984. Strijder voor het Vlaamse rechtsleven, Brussels, Doorbraak), a lawyer and one of the leading actors within the Flemish Movement of the twentieth century.

Dr. Valerie Vrancken (KU Leuven) published her Ph.D. dissertation on the Joyous Entries of the Brabantian dukes in the fifteenth century (De Blijde Inkomsten van de Brabantse hertogen. Macht, opstand en privileges in de vijftiende eeuw, Brussels, ASP).

\section{Doctoral Defences}

At least five researchers received their Ph.Ds. in legal historical topics in the course of 2018 . 
On 12 January 2018, Marlies Eggermont defended her Ph.D. at the university of Ghent on the juridicization in Belgium of the profession of midwives as of the nineteenth century (De juridisering van de beroepsuitoefening van de Belgische vroedvrouw vanaf de 19de eeuw: saltatoire evolutie).

On 21 March 2018, the author of these lines defended his own Ph.D. at KU Leuven, entitled Transregional Normativity in Learned Legal Practice. Loans and Credit in Consilia and Decisiones from the Northern and Southern Low Countries (c. 1500-1680).

On 9 May 2018, Ramses Delafontaine obtained his doctor's bull with a thesis on History and Historians in American Civil Law.

On 13 June 2018, Paolo Astorri successfully defended his Ph.D. at KU Leuven with his thesis on Lutheran Theology and Contract Law in Early Modern Germany (ca. 15201720).

On 3 July 2018, Marc Ronvaux obtained his doctoral degree in law at the UCLouvain with a thesis on the appeals from the Namur region with the Great Council of Mechelen in the eighteenth century (Le Grand Conseil de Malines et le droit namurois au XVIIIe siècle). 